OUTSTANDING SCHOLARSHIP from CAMBRIDGE titles!

Now in Paperback!

\section{Erasing the Invisible Hand}

Essays on an Elusive and Misused Concept in Economics

Warren J. Samuels

Assisted by Marianne F. Johnson and William H. Perry

\$29.99: Pb: 978-1-107-61316-4: 358 pp.

\section{Second Edition!}

Financial Markets and Institutions

\section{A European Perspective}

Jakob de Haan, Sander Oosterloo, and Dirk Schoenmaker

\$109.00: Hb: 978-1-107-02594-3

\$49.00: $\mathrm{Pb}: 978-1-107-63592-0: 496 \mathrm{pp}$.

\section{From Financial Crisis to Stagnation}

The Destruction of Shared Prosperity and the Role of Economics

Thomas I. Palley

\$60.00: Hb: 978-1-107-01662-0

\$27.99: Pb: 978-1-107-61246-4: 256 pp.

\section{Second Edition!}

\section{How Capitalism} Was Built

The Transformation of Central and Eastern Europe, Russia, the Caucasus, and Central Asia

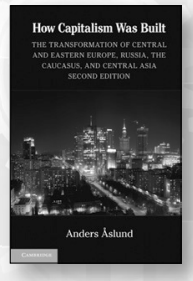

Anders Åslund

\$110.00: Hb: 978-1-107-02654-4

\$36.99: Pb: 978-1-107-62818-2: 436 pp.

Indigenous Peoples, Poverty, and Development

Edited by Gillette H. Hall and Harry Anthony Patrinos \$99.00: Hb: 978-1-107-02057-3: 424 pp.
International Liquidity and the Financial Crisis

William A. Allen

\$99.00: Hb: 978-1-107-03004-6: $267 \mathrm{pp}$.

Monetary Theory and Policy from Hume and Smith to Wicksell Money, Credit, and the Economy Arie Arnon

Historical Perspectives on Modern Economics \$39.99: Pb: 978-1-107-64273-7: 450 pp.

\section{Outsourcing \\ Economics}

Global Value Chains in Capitalist Development

William Milberg and Deborah Winkler \$99.00: Hb: 978-1-107-02699-5 \$36.99: Pb: 978-1-107-60962-4: $370 \mathrm{pp}$.

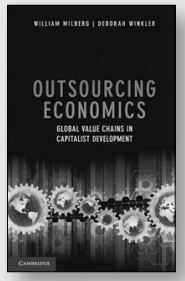

Questioning Credible Commitment Perspectives on the Rise of Financial Capitalism

Edited by D'Maris Coffman, Adrian Leonard, and Larry Neal Macroeconomic Policy Making \$99.00: Hb: 978-1-107-03901-8: 304 pp.

Schumpeterian Analysis of Economic Catch-up

Knowledge, Path-Creation, and the Middle-Income Trap

Keun Lee

\$55.00: Hb: 978-1-107-04268-1: 256 pp.

\section{Structural Dynamics and} Economic Growth

Edited by Richard Arena

and Pier Luigi Porta

\$99.00: Hb: 978-1-107-01596-8: 310 pp.

Prices subject to change. 
OUTSTANDING SCHOLARSHIP from CAMBRIDGE

The Clash of Economic Ideas

The Great Policy Debates and

Experiments of the Last Hundred Years

Lawrence $\mathrm{H}$. White

\$125.00: Hb: 978-1-107-01242-4

\$45.00: Pb: 978-1-107-62133-6: 440 pp.

\section{The Collected Writings}

of John Maynard Keynes

30 Volume Paperback Set*

John Maynard Keynes

Edited by Elizabeth Johnson,

Donald Moggridge, and Austin Robinson

Published on behalf of the

Royal Economic Society

\$875.00: 30 Pb Books: 978-1-107-67772-2: 15,053 pp.

*Also available as individual volumes.

\section{The Economics of Freedom}

Theory, Measurement, and

Policy Implications

Sebastiano Bavetta and Pietro Navarra

\$99.00: Hb: 978-1-107-01784-9: 222 pp.

\section{The IMF and Global Financial Crises}

Phoenix Rising?

Joseph P. Joyce

\$50.00: Hb: 978-0-521-87417-5: 257 pp.

\section{The Limits of Institutional} Reform in Development

Matt Andrews

\$50.00: Hb: 978-1-107-01633-0: 263 pp.

The New Economics of Inequality and Redistribution

Samuel Bowles

Federico Caffe Lectures

\$80.00: Hb: 978-1-107-01403-9

\$27.99: Pb: 978-1-107-60160-4: $208 \mathrm{pp}$.

\section{The World}

in the Model

How Economists

Work and Think

Mary S. Morgan

\$125.00: Hb: 978-1-107-00297-5

\$39.99: Pb: 978-0-521-17619-4: $445 \mathrm{pp}$.

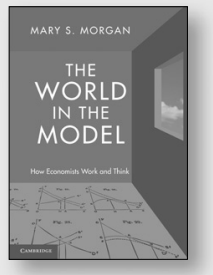

\section{Econometric Society Monographs}

Advances in Economics and Econometrics

Volumes 1, 2, and 3*

Theory and Applications

Tenth World Congress

Edited by Daron Acemoglu,

Manuel Arellano, and Eddie Dekel

\$500.00: 3 Volume Hb Set: 978-1-107-01721-4:

$1,712 \mathrm{pp}$.

\$175.00: 3 Volume Pb Set: 978-1-107-62886-1:

$1,700 \mathrm{pp}$.

*Also available as individual volumes.

Dynamic Models for

Volatility and Heavy Tails

With Applications to Financial and

Economic Time Series

Andrew C. Harvey

\$99.00: Hb: 978-1-107-03472-3

\$36.99: Pb: 978-1-107-63002-4: $279 \mathrm{pp}$.

\section{Second Edition!}

\section{Regression Analysis} of Count Data

A. Colin Cameron and Pravin K. Trivedi

\$130.00: Hb: 978-1-107-01416-9

\$60.00: Pb: 978-1-107-66727-3: 587 pp. 
OUTSTANDING SCHOLARSHIP from CAMBRIDGE

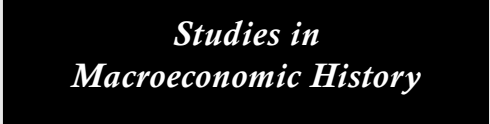

Credibility and the International Monetary Regime A Historical Perspective

Edited by Michael D. Bordo and Ronald MacDonald

\$99.00: Hb: 978-0-521-81133-0: $256 \mathrm{pp}$.

\section{The Great Recession}

Market Failure or Policy Failure?

Robert L. Hetzel

\$50.00: Hb: 978-1-107-01188-5: $400 \mathrm{pp}$

\section{After the Great Recession}

The Struggle for Economic Recovery and Growth

Edited by

Barry Z. Cynamon, Steven M. Fazzari, and Mark Setterfield

\$95.00: Hb: 978-1-107-01589-0: $354 \mathrm{pp}$.

\section{Against the Consensus}

Reflections on the Great Recession Justin Yifu Lin

\$29.99: Hb: 978-1-107-03887-5: 273 pp.

\section{Chile and the Neoliberal Trap}

The Post-Pinochet Era

Andrés Solimano

\$90.00: Hb: 978-1-107-00354-5: 182 pp.

\section{Currencies, Commodities and Consumption}

Kenneth W. Clements

\$110.00: Hb: 978-1-107-01476-3: 397 pp.
Doing Capitalism in the Innovation Economy Markets, Speculation and the State William H. Janeway \$34.99: Hb: 978-1-107-03125-8: 340 pp.

\section{Dynamic Modeling} and Applications for Global Economic Analysis

Edited by Elena Ianchovichina and Terrie L. Walmsley

\$115.00: Hb: 978-1-107-01169-4

\$49.00: Pb: 978-1-107-00243-2: 448 pp.

Economic Reform and Development in China

Yining Li

The Cambridge China

Library

\$115.00: Hb: 978-1-107-02405-2: $368 \mathrm{pp}$.

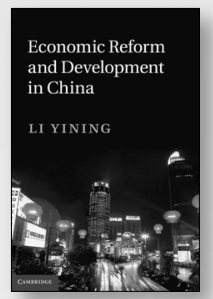

\section{Second Edition!}

\section{Economics}

\section{of Agglomeration}

Cities, Industrial Location, and Globalization

Masahisa Fujita

and Jacques-Francois Thisse

\$140.00: Hb: 978-1-107-00141-1

\$55.00: Pb: 978-0-521-17196-0: $600 \mathrm{pp}$

\section{Eminent Economists II}

Their Life and Work Philosophies

Edited by Michael Szenberg and Lall Ramrattan

\$99.00: Hb: 978-1-107-04053-3

\$32.99: Pb: 978-1-107-65636-9: 400 pp. 


\section{MACROECONOMIC DYNAMICS}

\section{Notes for Contributors}

Contributions. Contributions are welcome from all countries. They should be written in English.

Aims and Scope/Editorial Policy. Macroeconomic Dynamics publishes research of the highest theoretical, empirical or quantitative sophistication. Papers of high quality are welcomed from all areas of macroeconomics and from all parts of the world, as long as the research is founded in a rigorous scientific approach. Major advances in macroeconomics without immediate policy applications are also accepted, if they show potential for application in the future. Occasional book reviews, announcements, conference proceedings and interviews are also published. Special issues appear in the journal's Supplements Series, having its own Special Issues Editors. An electronic version of the journal will be published simultaneously with the paper version enabling immediate access to the best current research in Macroeconomics.

Home Page. The journal has a home page on the web which is a source of further information about the journal. The location of the home page is: http://econ.tepper.cmu. edu/barnett/MD.html. Information. about Macroeconomic Dynamics may also be viewed at www.journals.cambridge.org.

Manuscript Submissions. The submission procedure for this journal has been converted to electronic uploading of pdfs to the journal's server. To submit, follow the instructions provided at http://server1.tepper. $\mathrm{cmu} . e d u / \mathrm{md} /$ electronic_submission.htm. Questions about the submission procedure can be transmitted to the Editorial Information System Manager, Stephen Spear, at ss1f@andrew.cmu.edu, or to the Editor, William A. Barnett, at barnett@ku.edu.

Special Issues Submissions. The journal publishes special issues in its Supplement Series. Proposals for special issues should be sent to either of the journal's Special Issues Editors and should include a table of contents and one of more proposed guest editors.

Originality and Copyright. Manuscripts are accepted for review on the understanding that the same work has not been and will not be published nor is presently submitted for publication elsewhere. While under editorial review, it is the responsibility of the authors to keep the Editor informed about submissions, publication plans, and actual publication of related research or abstracts thereof in other outlets, including letters, journals, review publications, journals in other disciplines, conference proceedings, and published dissertations. It is further understood that all persons listed as authors have given their approval for the submission of the paper and that any person cited as a source of personal communication has approved such citation; written authorization may be required at the Editor's discretion. Authors are responsible for obtaining written permission to publish material for which they do not own the copyright. A Copyright Transfer Agreement, with certain specified rights reserved by the author, must be signed and returned to the Editor by a senior author of accepted manuscripts, prior to publication. This is necessary to enable the publisher to ensure the wide distribution of the author's(s') work and the protection of both the author and the publisher under copyright law. Articles and other material published in Macroeconomic Dynamics represent the opinions of the authors and should not be construed to reflect the opinions of the Editor, Advisory Board, Editorial Board, or the Publisher.

Preparation of a Manuscript. The entire manuscript (including notes and references) should be produced as double spaced typescripton $8 \frac{1}{2} \times 11$-inch or A4 white paper, with wide margins to accommodate copyediting. The manuscript should be converted to a pdf for submission by upload-ing to the journal's server. The publisher asks that you provide a PDF file of the fi-nal version of your paper, together with a copy of the word processing source file in which the paper was written. Pages should be numbered consecutively. Page 1 should provide the article, author's(s') names (in the form preferred for publication, complete affiliation, phone, fax and e-mail num-bers (if available). At the bottom of Page 1 place any footnotes to the title or authors, indicated by superscripts *,**, etc. Page 2 should contain a proposed running head (abbreviated form of the title) of up to 40 characters, and the name and mailing ad-dress, telephone, fax and e-mail numbers of the author to whom proof's should be sent Page 3 should contain a short abstract of the paper in less than 150 words. The abstract will appear at the head of the article when published in the journal. A list of three or four keywords or terms should also be included. The full text of the manuscript should begin on Page 4.

Equations. All equations should be typewritten and the numbers for displayed equations should be placed in parenthesis in the right margin. References to equation should simply use the form "(3)." Superscripts and subscripts should be typed clearly above and below the line, respectively. Theorem, lemma, and proposition statements should appear in italic print. End-of-proof signposts should appear as such: either or Q.E.D., typed in italics. Authors are encouraged to use the following order for parentheses: $\{[(\ldots)]\}$.

Tables and Figures. If possible, the publisher asks that you include all graphics (charts, diagrams or other art work) at the end of the paper, indicating in the body of the paper where each graphic should appear. If it is not possible for you to include the graphics files in the word processor source code, you should upload the individual graphics files separately after you upload the PDF and source files for your paper.

References. References should be cited in the text by the author's last name and the date of publication. Complete bibliographic information for each citation should be included in the list of references. References should be typed in alphabetical order in the style of the following examples:

Monograph:

Stokey, Nancy L. and Robert E. Lucas, Jr. with Edward Prescott (1989) Re-cursive Methods in Economic Dynamics. Cambridge, MA: Harvard University Press Chapter in an Edited Volume:

Danthine, Jean-Pierre and John B. Donaldson (1995) Computing equilibria of nonoptimal economies. In Thomas $\mathrm{F}$. Cooley (ed.), Frontiers of Business Cycle Research, pp. 65-97. Princeton, NJ: Princeton University Press.

Journal Article:

Epstein, Larry G. and Stanley Zin (1989) Substitution, risk aversion and the temporal behavior of consumption and asset returns I: A theoretical framework. Econometrica 42, 937-969.

Article in Press:

Huang, He, Selahattin Imrohoroglu, and Thomas J. Sargent (in press) Two computational experiments to fund Social Security. Macroeconomic Dynamics.

Journal names should not be abbreviated. Footnotes. Where more that a simple source citation is called for, footnotes may be used. These should be numbered consecutively throughout the text and typed together at the end of the paper before the references. Source citations within footnotes follow the same style as citations within the text.

Copyediting and Proofreading. The publisher reserves the right to copyedit and proofread all articles for publication, but the corresponding author will receive page proofs for final proofreading. These should be checked and returned within five days of receipt. The publisher reserves the right to charge authors for excessive correction of non-typographicalerrors.

Offprints. The corresponding author will receive 25 free offprints of their article free of charge; additional numbers may be purchased if ordered at proof stage (an order form will be sent with proofs). 
MACROECONOMIC DYNAMICS

Volume 18, Number 8, December 2014

Contents

\section{ARTICLES}

How Do International Stock Markets Respond to Oil Demand and Supply Shocks?

Jochen H. F. Güntner

Optimal Taxation and Social Networks

Marcelo Arbex and Dennis O'Dea

Unifying Time-To-Build Theory

Mauro Bambi and Franco Gori

Banks' Precautionary Capital and Credit Crunches

Fabián Valencia

Transaction Costs, Nonfundamental Uncertainty, and the Exchange Rate Disconnect

Nan Li

Economic Growth and Evolution: Parental Preference for Quality and Quantity of Offspring

Jason Collins, Boris Baer, and Ernst Juerg Weber

Dynamic Effects of Foreign Direct Investment When Credit Markets Are Imperfect

Thomas Gall, Marc Schiffbauer, and Julia Kubny

\section{INTERVIEW}

Interview with Jean-François Mertens (1946-2012)

Interviewed by Françoise Forges

NOTES

A Note on Money and the Conduct of Monetary Policy

Jagjit S. Chadha, Luisa Corrado, and Sean Holly

1854 